\title{
Quantification of Yield Loss Caused by Triticum mosaic virus and Wheat streak mosaic virus in Winter Wheat Under Field Conditions
}

\author{
E. Byamukama and S. N. Wegulo, Department of Plant Pathology, University of Nebraska-Lincoln, Lincoln, NE 68583; S. Tatineni, \\ USDA-ARS and Department of Plant Pathology, University of Nebraska-Lincoln; G. L. Hein, Department of Entomology, University \\ of Nebraska-Lincoln; R. A. Graybosch, USDA-ARS and Department of Agronomy and Horticulture, University of Nebraska-Lincoln; \\ P. S. Baenziger, Department of Agronomy and Horticulture, University of Nebraska-Lincoln; and R. French, USDA-ARS and Depart- \\ ment of Plant Pathology, University of Nebraska-Lincoln
}

\begin{abstract}
Byamukama, E., Wegulo, S. N., Tatineni, S., Hein, G. L., Graybosch, R. A., Baenziger, P. S., and French, R. 2014. Quantification of yield loss caused by Triticum mosaic virus and Wheat streak mosaic virus in winter wheat under field conditions. Plant Dis. 98:127-133.

Triticum mosaic virus (TriMV) and Wheat streak mosaic virus (WSMV) infect winter wheat (Triticum aestivum) in the Great Plains region of the United States. The two viruses are transmitted by wheat curl mites (Aceria tosichella), which also transmit High Plains virus. In a field study conducted in 2011 and 2012, winter wheat cultivars Millennium (WSMV-susceptible) and Mace (WSMV-resistant) were mechanically inoculated with TriMV, WSMV, TriMV+WSMV, or sterile water at the two-leaf growth stage. Chlorophyll meter (soil plant analysis development [SPAD]) readings, area under the SPAD progress curve (AUSPC), grain yield (=yield), yield components (spikes $/ \mathrm{m}^{2}$, kernels/spike, 1,000-kernel weight), and aerial dry matter were determined. In Millennium, all measured variables were significantly reduced by single or double virus inoculation, with the greatest reduc-

tions occurring in the double-inoculated treatment. Among the yield components, the greatest reductions occurred in spikes $/ \mathrm{m}^{2}$. In Mace, only AUSPC was significantly reduced by the TriMV+WSMV treatment in 2012. There was a significant $(P \leq 0.05)$, negative linear relationship between SPAD readings and day of year in all inoculation treatments in Millennium and in the TriMV+WSMV treatment in Mace. There were significant $(P \leq 0.05)$, positive linear relationships between yield and SPAD readings and between yield and aerial dry matter in Millennium but not in Mace. The results from this study indicate that under field conditions, (i) Mace, a WSMV-resistant cultivar, is also resistant to TriMV, and (ii) double inoculation of winter wheat by TriMV and WSMV exacerbates symptom expression and yield loss in a susceptible cultivar.
\end{abstract}

Triticum mosaic virus (TriMV), the type member of the genus Poacevirus in the family Potyviridae (22), is a newly discovered virus that infects wheat (Triticum aestivum L.) (16). It was first isolated in Kansas in 2006 from wheat plants with mosaic symptoms (16) and subsequently shown to be transmitted by the wheat curl mite (WCM, Aceria tosichella Keifer) (15). Recent field surveys indicated that TriMV is widely distributed in the Great Plains region of the United States (2,3). These surveys also showed that Wheat streak mosaic virus (WSMV), the type member of the genus Tritimovirus in the family Potyviridae and which also is transmitted by the WCM (18), is the predominant virus infecting wheat in the Great Plains region. A survey of the central Great Plains states of Colorado, Kansas, Nebraska, and South Dakota revealed a high frequency (91\%) of co-infection of wheat by TriMV and WSMV (3).

The highly frequent occurrence of double infection of wheat by TriMV and WSMV implies that there is potential for exacerbated yield loss in wheat under natural field conditions. In greenhouse experiments, it was demonstrated that double infections of wheat with TriMV and WSMV induced disease synergism with severe leaf deformation, bleaching, and stunting (21). Previously, we showed that both single and double infections of WSMV-susceptible wheat cv. Millennium with TriMV and WSMV under greenhouse conditions significantly reduced chlorophyll content, number of tillers per plant, shoot and dry weight, and total nitrogen and carbon content relative to noninfected plants (4). However, the greatest reductions occurred in the double infection treatment. In contrast, single and double infections of WSMV-resistant cv. Mace

Corresponding author: S. N. Wegulo, E-mail: swegulo2@unl.edu

Accepted for publication 20 August 2013

http://dx.doi.org/10.1094/PDIS-04-13-0419-RE

(C) 2014 The American Phytopathological Society with TriMV and WSMV had no significant effect on all of these yield determinants except nitrogen content (4). In the same study, TriMV caused more severe symptoms than WSMV in both cultivars, suggesting that TriMV has the potential to cause greater yield loss than WSMV. These studies show the potential negative effects on yield determinants and yield when a susceptible wheat cultivar is co-infected with TriMV and WSMV.

Previous research has shown that WSMV by itself can cause significant yield losses in wheat $(6,17,19)$. The economic impact of these losses, some of which can approach $100 \%$ (6), can be devastating to farmers and the wheat industry. An economic analysis conducted by Velandia et al. (23) showed a marginal loss (or marginal profit reduction) due to WSMV of up to $\$ 464.5 / \mathrm{ha}$. This loss was higher in irrigated wheat than in dryland wheat due to the reduced water use efficiency that results when wheat is infected by WSMV (12,23). Recently, Seifers et al. (14) reported that TriMV caused significant yield and volume weight reductions in the wheat cultivars Danby, RonL, and Jagalene, but not in the wheat breeding line KS96HW10-3. Because TriMV is a newly discovered virus, research is needed, especially under field conditions, to elucidate the effects of its synergistic interactions with WSMV on yield reduction in wheat. We report here the effects of single (TriMV or WSMV) and double (TriMV+WSMV) inoculation on yield and yield components of WSMV-susceptible Millennium and WSMVresistant Mace under field conditions in two growing seasons.

\section{Materials and Methods}

Virus inoculum source, maintenance, and inoculum preparation. WSMV Sidney 81 isolate and a TriMV isolate were maintained on winter wheat cv. Millennium (PI 613099) in the greenhouse. The WSMV Sidney 81 isolate was obtained from an infectious cDNA clone whose in vitro-generated RNA transcripts were inoculated to wheat seedlings at the single-leaf stage (5). The TriMV isolate was originally obtained from wheat plants collected from Red Willow County, NE and confirmed to be TriMV by im- 
munology and polymerase chain reaction (PCR) (22). This isolate was confirmed negative for WSMV and HPV by PCR. TriMV and WSMV inocula were prepared from the top fully developed Millennium leaves exhibiting severe symptoms of TriMV or WSMV in the greenhouse. The harvested leaves were ground in a general extraction buffer (1:10 wt/vol) using a mortar and pestle. The extraction buffer consisted of sodium sulfite $(6 \%)$, polyvinylpyrrolidone MW 24-40,000 (85\%), and powdered chicken egg albumin (9\%) dissolved in phosphate buffer saline Tween 20 (PBS-T). TriMV+WSMV inoculum was prepared by mixing equal volumes of TriMV and WSMV inocula. To match the concentration of the mixed inoculum, TriMV or WSMV inoculum was further diluted $1: 1(\mathrm{vol} / \mathrm{vol})$ with extraction buffer to a final dilution of $1: 20$. The inoculum was kept on ice until inoculation on the same day it was prepared.

Treatments and experimental design. Two winter wheat cultivars, Millennium (WSMV-susceptible) and Mace (PI 651043, WSMV-resistant), were used in this study. Millennium is a popular winter wheat cultivar released for its superior agronomic performance and broad adaptation to rain-fed wheat production systems in Nebraska and adjacent states (1). Mace was recently released primarily for its resistance to WSMV and adaptation to rain-fed and irrigated wheat production systems in Nebraska and adjacent states (7). Seeding of both cultivars was done at the University of Nebraska Agricultural Research and Development Center near Mead, NE on 30 September 2010 (first season) and on 20 September 2011 (second season) using a small plot drill at a seeding rate of $101 \mathrm{~kg} / \mathrm{ha}$. Plot size was $1.2 \times 1.8 \mathrm{~m}$, and each plot consisted of 6 rows. At the two-leaf growth stage, both cultivars were mechanically inoculated with TriMV, WSMV, TriMV+WSMV, or sterile water (control) by the air-blast technique (11). A spray gun attached to a 0.5-liter inoculum reservoir was connected to an air compressor maintained at a pressure of $621 \mathrm{kPa}$. A volume of 60 $\mathrm{ml}$ of inoculum mixed with $0.6 \mathrm{~g}$ of Carborundum was delivered to each plot. The inoculum reservoir was washed with water and soap and then rinsed with water between inoculum treatments. The experimental design was a split plot in randomized complete blocks with four replications. Main plots were the two cultivars and subplots were the four inoculation treatments. Individual plots were separated by $0.6-\mathrm{m}$-wide alleys.

Disease assessment and harvesting. Disease severity was assessed every 9 to 11 days starting when plants had begun to regrow in spring by measuring relative chlorophyll content of leaves. Chlorophyll content was measured nondestructively (13) using a Soil Plant Analytical Development (SPAD) meter (model 502 Plus, Konica Minolta Sensing, Inc., Osaka, Japan) (8). Higher SPAD readings indicate higher intensity of greenness of leaf tissue (healthy or mild symptoms), while lower SPAD readings indicate lower chlorophyll levels and more severe symptoms (4). SPAD readings have previously been used to accurately and objectively quantify WSMV and TriMV symptoms in the greenhouse (4) and WSMV symptoms in the field (20). In each treatment, SPAD readings were taken on 10 randomly selected tillers ( 5 from each of the two outer rows). In order to avoid interference of foliar fungal diseases on yield and chlorophyll content, a single Twinline (metconazole+pyraclostrobin; BASF Corp., Research Triangle Park, NC) fungicide spray was applied when wheat was at Zadoks growth stage 45 (24). The fungicide was applied at a rate of 0.586 liters a.i./ha at a delivery rate of 200 liters/ha of spray volume and a pressure of $276 \mathrm{kPa}$ using a $\mathrm{CO}_{2}$-powered backpack sprayer equipped with four Teejet 800-1 VS nozzles spaced $30.5 \mathrm{~cm}$ apart on a boom. To assess the efficiency of virus inoculation in plots, six randomly selected tillers ( 3 tillers per outer row) were sampled every 9 to 11 days in spring and tested for virus presence using enzyme-linked immunosorbent assay (ELISA). Samples from control plots were negative for both WSMV and TriMV, whereas samples from virus-inoculated plots were positive for the respective viruses.

Harvesting was done by hand in 2011 and by a sickle mower in 2012. Plot edges were trimmed so that the harvested plot size was
$0.8 \times 1.2 \mathrm{~m}$ in both years. In both years, the straw was cut at the base with spikes still attached to the wheat plants. The straw and the spikes from each plot were put in a prelabeled paper bag and transported to the greenhouse. Spikes from each plot were manually cut, counted, and threshed using a single head thresher (Precision Machines Inc., Lincoln, NE). Spikes $/ \mathrm{m}^{2}$, number of kernels per spike, grain yield (=yield), and 1,000-kernel weight were determined. The straw was dried for $72 \mathrm{~h}$ at $60^{\circ} \mathrm{C}$ in a hot air blast oven, and aerial dry matter weight was determined.

Data analysis. SPAD readings were graphed against time of sampling (day of year [DOY]) to show changes in SPAD readings over time. To determine if symptom severity was related to time of sampling, SPAD readings were regressed on time of sampling (DOY). Area under the SPAD progress curve (AUSPC) was calculated using trapezoidal integration (10). Final SPAD readings, AUSPC, spikes $/ \mathrm{m}^{2}$, number of kernels per spike, yield, 1,000-kernel weight, and aerial dry matter weight were subjected to analysis of variance using PROC MIXED (SAS version 9.2; SAS Institute, Cary, NC). Treatment effects or their interactions were considered significant at $P \leq 0.05$. PROC GLIMMIX (SAS v.9.2) was used to separate cultivar by inoculation interaction least squares means at $P=0.05$. Fixed effects were cultivar and inoculation. Replication and residual error were the random effects. To determine the relationship between relative chlorophyll content (SPAD readings) and yield, the yield and the SPAD readings data for the respective treatments within each cultivar were subjected to linear regression analysis using PROC REG (SAS v.9.2). The relationship between yield and aerial dry matter weight for each cultivar was similarly modeled using PROC REG.

\section{Results}

Significance of main effects and their interaction. $F$ values for cultivar $(\mathrm{C})$ were significant $(P \leq 0.05)$ in both years for final SPAD readings, AUSPC, spikes $/ \mathrm{m}^{2}$, yield, and aerial dry matter (Table 1). $F$ values for cultivar were significant for kernels/spike in 2012 but not in 2011 and nonsignificant for 1,000-kernel weight in both years. $F$ values for virus inoculation treatment (I) and $\mathrm{C} \times \mathrm{I}$ interaction were significant for all variables in both years (Table 1).

Effects of virus inoculation treatments on measured variables. In Mace in 2011, there were no significant differences among virus inoculation treatments for all measured variables (final SPAD readings, AUSPC, spikes $/ \mathrm{m}^{2}$, kernels/spike, yield, 1,000-kernel weight, and aerial dry matter) (Table 2). The same result was observed in 2012 except for the TriMV+WSMV treatment, which resulted in a significantly smaller AUSPC value compared to the other inoculation treatments (Table 3).

SPAD readings in the TriMV+WSMV treatment in Millennium were 39, 34, and 30\% lower than in the control, TriMV, and WSMV treatments, respectively, in 2011, and 46, 20, and $22 \%$ lower than in the control, TriMV, and WSMV treatments, respectively, in 2012, indicating a strong disease synergism resulting from co-infection of Millennium with the two viruses. The TriMV+WSMV treatment was the most detrimental in Millennium, resulting in the smallest measurements for all variables (Tables 2 and 3). The most detrimental effect of this treatment in 2011 occurred on yield (reduced by 96, 87, and 92\% compared to the control, TriMV, and WSMV treatments, respectively); spikes $/ \mathrm{m}^{2}$ (reduced by 89,86 , and $88 \%$ compared to the control, TriMV, and WSMV treatments, respectively); and aerial dry matter (reduced by 90, 84, and $87 \%$ compared to the control, TriMV, and WSMV treatments, respectively). A similar result was observed for the TriMV+WSMV treatment in Millennium in 2012 except that the reductions were smaller (Table 3): yield was reduced by 81,53 , and $50 \%$ compared to the control, TriMV, and WSMV treatments, respectively; spikes $/ \mathrm{m}^{2}$ were reduced by 85,59 , and $36 \%$ compared to the control, TriMV, and WSMV treatments, respectively; and aerial dry matter was reduced by 79,24 , and $43 \%$ compared to the control, TriMV, and WSMV treatments, respectively. Reductions in spikes $/ \mathrm{m}^{2}$, yield, and 1,000-kernel weight were significantly greater for the TriMV compared to the WSMV treatment in 
2011. In 2012, reduction in only spikes $/ \mathrm{m}^{2}$ was significantly greater in the TriMV compared to the WSMV treatment. Overall, with the exception of 1,000-kernel weight in 2012, virus inoculation treatments reduced measured variables in Millennium but not in Mace (Tables 2 and 3).

Variation of chlorophyll content over time. Chlorophyll content (indicated by SPAD readings) varied between cultivars and among virus inoculation treatments over time (Fig. 1). In Mace, SPAD readings were similar among treatments and slightly declined over time in both 2011 and 2012 (Fig. 1A and C). In Millennium, SPAD readings declined over time for all treatments in 2011 and all treatments except the control in 2012. The TriMV+WSMV treatment consistently resulted in the lowest SPAD readings in both years, whereas SPAD readings in the TriMV and WSMV treatments were comparable but lower than those in the control treatment throughout the sampling period in both years (Fig. 1B and D). In Mace, there was a significant, negative linear relationship between SPAD readings and DOY only for the TriMV+WSMV inoculation treatment in 2011 (Fig. 2A and C). In Millennium, there was a significant, negative linear relationship between SPAD readings and DOY for all virus inoculation treatments in both years (Fig. 2B and D).

Relationship between yield and SPAD readings. In both years, there was a significant, positive linear relationship between yield

Table 1. $P$ values from the analysis of variance of data from experiments conducted to quantify the effect of single and double inoculation of two winter wheat cultivars with Triticum mosaic virus and Wheat streak mosaic virus on grain yield and yield components in the 2011 and 2012 growing seasons

\begin{tabular}{|c|c|c|c|c|c|c|c|c|}
\hline \multirow[b]{2}{*}{ Source } & \multirow[b]{2}{*}{$\mathbf{d f}^{\mathbf{z}}$} & \multicolumn{7}{|c|}{$P$ value } \\
\hline & & $\begin{array}{l}\text { Final SPAD } \\
\text { reading }\end{array}$ & AUSPC & Spikes/m² & Kernels/spike & $\begin{array}{c}\text { Yield } \\
\text { (kg/ha) }\end{array}$ & $\begin{array}{c}\text { 1,000-kernel } \\
\text { weight (g) }\end{array}$ & $\begin{array}{c}\text { Aerial dry } \\
\text { matter }\left(\mathrm{g} / \mathbf{m}^{2}\right)\end{array}$ \\
\hline \multicolumn{9}{|l|}{2011} \\
\hline Cultivar (C) & 1 & 0.0002 & 0.0006 & 0.0174 & 0.6090 & 0.0185 & 0.1715 & 0.0222 \\
\hline Replication (R) & 3 & & & & & & & \\
\hline Error (a) & 3 & & & & & & & \\
\hline Inoculation (I) & 3 & $<0.0001$ & $<0.0001$ & $<0.0001$ & 0.0065 & $<0.0001$ & 0.0001 & $<0.0001$ \\
\hline $\mathrm{C} \times \mathrm{I}$ & 3 & $<0.0001$ & $<0.0001$ & $<0.0001$ & 0.0047 & $<0.0001$ & 0.0003 & $<0.0001$ \\
\hline Error (b) & 18 & & & & & & & \\
\hline Total & 31 & & & & & & & \\
\hline \multicolumn{9}{|l|}{2012} \\
\hline Cultivar (C) & 1 & $<0.0001$ & 0.0004 & 0.0005 & 0.0135 & 0.0122 & 0.5043 & 0.0006 \\
\hline Replication (R ) & 3 & & & & & & & \\
\hline Error (a) & 3 & & & & & & & \\
\hline Inoculation (I) & 3 & $<0.0001$ & $<0.0001$ & $<0.0001$ & $<0.0001$ & $<0.0001$ & 0.0098 & $<0.0001$ \\
\hline $\mathrm{C} \times \mathrm{I}$ & 3 & $<0.0001$ & $<0.0001$ & $<0.0001$ & 0.0001 & $<0.0001$ & 0.0002 & $<0.0001$ \\
\hline Error (b) & 18 & & & & & & & \\
\hline Total & 31 & & & & & & & \\
\hline
\end{tabular}

${ }^{\text {z }}$ Abbreviations: df, degrees of freedom; SPAD, soil plant analysis development; AUSPC, area under the SPAD progress curve.

Table 2. Treatment means for the effects of single and double inoculation of two winter cultivars with Triticum mosaic virus (TriMV) and Wheat streak mosaic virus (WSMV) on grain yield and yield components in the 2011 growing season

\begin{tabular}{|c|c|c|c|c|c|c|c|}
\hline Treatment & $\begin{array}{c}\text { Final } S^{S P A D}{ }^{z} \\
\text { reading }\end{array}$ & AUSPC & Spikes/m² & Kernels/spike & $\begin{array}{l}\text { Yield } \\
\text { (kg/ha) }\end{array}$ & $\begin{array}{c}\text { 1,000-kernel } \\
\text { weight (g) }\end{array}$ & $\begin{array}{c}\text { Aerial dry } \\
\text { matter }\left(\mathrm{g} / \mathbf{m}^{2}\right)\end{array}$ \\
\hline \multicolumn{8}{|l|}{ Mace } \\
\hline TriMV & $44.35 \mathrm{a}$ & $2,367.96 \mathrm{a}$ & $1,083.32 \mathrm{a}$ & $17.53 \mathrm{ab}$ & $3,476.31 \mathrm{~b}$ & $19.75 \mathrm{~b}$ & $441.16 \mathrm{ab}$ \\
\hline WSMV & $44.95 \mathrm{a}$ & $2,347.96 \mathrm{a}$ & $1,082.93 \mathrm{a}$ & $17.01 \mathrm{abc}$ & $3,744.46 \mathrm{~b}$ & $20.54 \mathrm{~b}$ & $450.44 \mathrm{ab}$ \\
\hline TriMV+WSMV & $43.08 \mathrm{ab}$ & $2,358.76 \mathrm{a}$ & $1,078.23 \mathrm{a}$ & $17.04 \mathrm{abc}$ & $3,530.50 \mathrm{~b}$ & $20.23 \mathrm{~b}$ & $436.51 \mathrm{ab}$ \\
\hline Control & $44.35 \mathrm{a}$ & $2,365.05 \mathrm{a}$ & $1,125.79 \mathrm{a}$ & $17.13 \mathrm{abc}$ & $3,804.57 \mathrm{~b}$ & $20.05 \mathrm{~b}$ & $487.59 \mathrm{ab}$ \\
\hline \multicolumn{8}{|l|}{ Millennium } \\
\hline TriMV & $38.25 \mathrm{c}$ & $1,955.00 \mathrm{c}$ & $753.24 \mathrm{~b}$ & $14.21 \mathrm{bc}$ & $1,590.09 \mathrm{~d}$ & $14.91 \mathrm{c}$ & $320.42 \mathrm{c}$ \\
\hline WSMV & $36.30 \mathrm{c}$ & $1,915.81 \mathrm{c}$ & $913.21 \mathrm{a}$ & $13.56 \mathrm{bc}$ & $2,500.75 \mathrm{c}$ & $19.17 \mathrm{~b}$ & 394.72 bc \\
\hline TriMV+WSMV & $25.40 \mathrm{~d}$ & $1,535.59 \mathrm{~d}$ & $105.33 \mathrm{c}$ & $11.39 \mathrm{c}$ & $203.42 \mathrm{e}$ & $14.38 \mathrm{c}$ & $51.08 \mathrm{~d}$ \\
\hline Control & $41.60 \mathrm{~b}$ & $2,207.26 \mathrm{~b}$ & $936.52 \mathrm{a}$ & $22.69 \mathrm{a}$ & $5,282.08 \mathrm{a}$ & $24.61 \mathrm{a}$ & $534.03 \mathrm{a}$ \\
\hline
\end{tabular}

${ }^{\mathrm{z}}$ Abbreviations: SPAD, soil plant analysis development; AUSPC, area under the SPAD progress curve. Means followed by the same letter(s) within a column are not significantly different according to least significant difference test at $P=0.05$.

Table 3. Treatment means for the effects of single and double inoculation of two winter cultivars with Triticum mosaic virus (TriMV) and Wheat streak mosaic virus (WSMV) on grain yield and yield components in the 2012 growing season

\begin{tabular}{|c|c|c|c|c|c|c|c|}
\hline Treatment & $\begin{array}{l}\text { Final } \text { SPAD }^{z} \\
\text { reading }\end{array}$ & AUSPC & Spikes/m² & Kernels/spike & $\begin{array}{l}\text { Yield } \\
\text { (kg/ha) }\end{array}$ & $\begin{array}{l}\text { 1,000-kernel } \\
\text { weight (g) }\end{array}$ & $\begin{array}{c}\text { Aerial dry } \\
\text { matter }\left(\mathrm{g} / \mathrm{m}^{2}\right)\end{array}$ \\
\hline \multicolumn{8}{|l|}{ Mace } \\
\hline TriMV & $45.30 \mathrm{a}$ & $2,392.14 \mathrm{a}$ & $967.47 \mathrm{a}$ & $16.06 \mathrm{a}$ & $4,277.91 \mathrm{a}$ & $25.79 \mathrm{~b}$ & $668.20 \mathrm{ab}$ \\
\hline WSMV & $45.43 \mathrm{a}$ & $2,387.79 \mathrm{a}$ & $947.17 \mathrm{a}$ & $16.99 \mathrm{a}$ & $4,193.06 \mathrm{a}$ & $25.73 \mathrm{~b}$ & $691.49 \mathrm{a}$ \\
\hline TriMV+WSMV & $44.43 \mathrm{a}$ & $2,228.39 \mathrm{~b}$ & $953.23 \mathrm{a}$ & $16.02 \mathrm{a}$ & $4,014.81 \mathrm{a}$ & $25.89 \mathrm{~b}$ & $668.07 \mathrm{ab}$ \\
\hline Control & $45.00 \mathrm{a}$ & $2,388.91 \mathrm{a}$ & $980.48 \mathrm{a}$ & $18.18 \mathrm{a}$ & $4,427.22 \mathrm{a}$ & $24.59 \mathrm{~b}$ & $737.95 \mathrm{a}$ \\
\hline \multicolumn{8}{|l|}{ Millennium } \\
\hline TriMV & $28.55 \mathrm{~b}$ & $1,619.00 \mathrm{c}$ & $364.64 \mathrm{c}$ & $8.03 \mathrm{~b}$ & $2,283.53 \mathrm{~b}$ & $24.84 \mathrm{~b}$ & $164.80 \mathrm{c}$ \\
\hline WSMV & $29.63 \mathrm{~b}$ & $1,649.58 \mathrm{c}$ & $574.02 \mathrm{~b}$ & $8.56 \mathrm{~b}$ & $2,457.60 \mathrm{~b}$ & $25.05 \mathrm{~b}$ & $217.98 \mathrm{c}$ \\
\hline TriMV+WSMV & $22.97 \mathrm{c}$ & $1,294.04 \mathrm{~d}$ & $131.60 \mathrm{~d}$ & $6.74 \mathrm{~b}$ & $950.30 \mathrm{c}$ & $23.78 \mathrm{~b}$ & $125.03 \mathrm{c}$ \\
\hline Control & $42.50 \mathrm{a}$ & $2,237.62 \mathrm{~b}$ & $900.07 \mathrm{a}$ & $19.05 \mathrm{a}$ & $4,909.73 \mathrm{a}$ & $30.42 \mathrm{a}$ & $590.43 \mathrm{~b}$ \\
\hline
\end{tabular}

${ }^{\mathrm{z}}$ Abbreviations: SPAD, soil plant analysis development; AUSPC, area under the SPAD progress curve. Means followed by the same letter(s) within a column are not significantly different according to least significant difference test at $P=0.05$. 
and SPAD readings in Millennium but not in Mace (Fig. 3). In Millennium, 58 and $80 \%$ of the variation in yield was explained by variation in SPAD readings in 2011 and 2012, respectively.

Relationship between yield and aerial dry matter. Yield had a significant, positive linear relationship with aerial dry matter in Millennium but not in Mace in both years (Fig. 4). In Millennium, 72 and $78 \%$ of the variation in yield was explained by variation in aerial dry matter in 2011 and 2012, respectively.

\section{Discussion}

To the best of our knowledge, this is the first study to demonstrate the effect of single and double inoculation of TriMV and WSMV on yield and yield components of winter wheat under field conditions. The double inoculation dramatically reduced yield in the WSMV-susceptible Millennium. These results demonstrate a synergistic effect on yield loss when the two viruses co-infect a susceptible winter wheat cultivar under field conditions.

These results are consistent with results from greenhouse studies (4). Tatineni et al. (21) found that when the WSMV-susceptible wheat cultivars Arapahoe and Tomahawk were doubly infected with TriMV and WSMV at $19^{\circ} \mathrm{C}$ and 20 to $26^{\circ} \mathrm{C}$, disease synergism was induced at both temperature regimes with severe leaf deformation, bleaching, and stunting. There was a 2.2- to 7.4-fold increase in accumulation of both viruses over single infections at
14 days postinoculation (dpi). At $28 \mathrm{dpi}$ at 20 to $26^{\circ} \mathrm{C}$, the concentration of TriMV was increased by 1.4 - to 1.8 -fold, whereas WSMV concentration was decreased to 0.5 -fold. In the same study, TriMV and WSMV replicated poorly in doubly infected Mace at $19^{\circ} \mathrm{C}$ with no synergistic interaction, but accumulated at moderate levels and caused mild to moderate disease synergism at 20 to $26^{\circ} \mathrm{C}$.

Under field conditions as in the current study, daytime temperatures often exceed $30^{\circ} \mathrm{C}$ in the summer. Such high temperatures are likely to increase TriMV and WSMV synergism in a doubly infected susceptible cultivar. In the current study, the most severe symptoms (yellowing and stunting) were observed in the TriMV+WSMV treatment in Millennium. This may explain the drastic yield loss in this cultivar. Interestingly, despite such high temperatures in the field, there was a nonsignificant decrease in yield in Mace singly or doubly inoculated with TriMV and WSMV in both years, indicating that Mace was resistant to both viruses under field conditions.

In a greenhouse study with the same cultivars and virus inoculation treatments as in the current field study, Byamukama et al. (4) obtained similar results to those in the current field study. The TriMV+WSMV treatment caused more severe symptoms and was more detrimental to yield determinants (tillers per plant, shoot and root weight, and total nitrogen and carbon) than the TriMV or
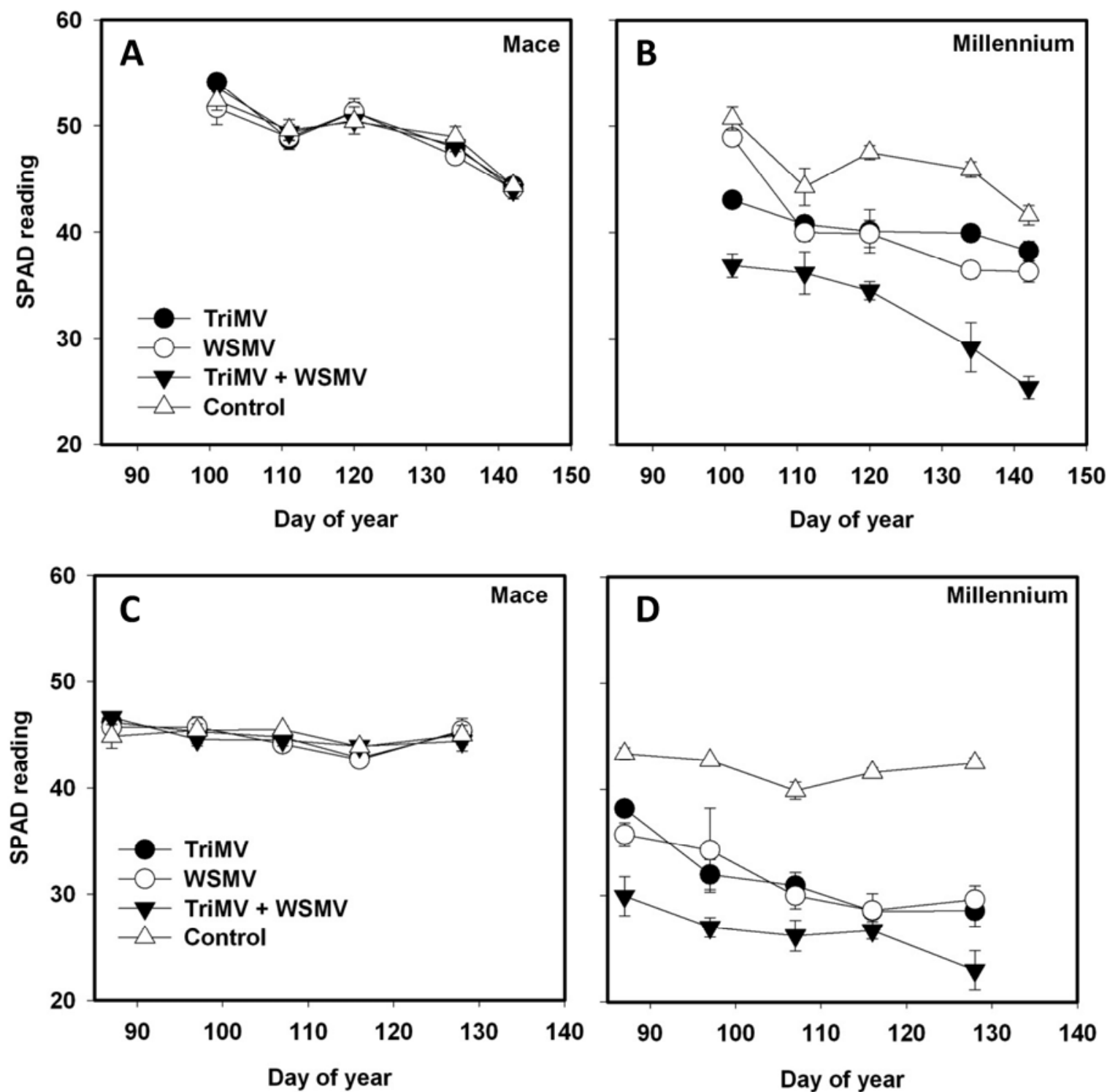

Fig. 1. Soil plant analysis development (SPAD) readings over time among treatments in two winter wheat cultivars, Mace and Millennium, in the 2011 (A and B) and 2012 (C and $\mathrm{D}$ ) growing seasons. Each data point is the mean of four replicates. 
WSMV treatment in Millennium. However, single or double inoculation of Mace with the two viruses had little or no effect on yield determinants.

Because TriMV is a newly discovered virus of wheat, little work has been done to demonstrate its effect on yield under field conditions. In a 2-year field study, Seifers et al. (14) measured yield in healthy and TriMV-infected cultivars Danby, RonL, Jagalene, and wheat breeding line KS96HW10-3. Their data show 23, 55, 17, and $1 \%$ yield loss in Danby, RonL, Jagalene, and KS96HW10-3, respectively, in the first year of the study, and 24, 76, 23, and $2 \%$ yield loss, respectively, in the second year. In the current study, we found yield losses due to TriMV of 70 and $9 \%$ in Millennium and Mace, respectively, in 2011, and yield losses of 53 and $3 \%$ in the same cultivars, respectively, in 2012. These data show that the amount of yield loss due to TriMV under field conditions is cultivar-dependent. The cultivar RonL and wheat line KS96HW10-3 carry the Wsm-2 gene, which confers resistance to WSMV, but not to TriMV. The cultivars Millennium, Danby, and Jagalene have no resistance genes. Mace, which was resistant to both TriMV and WSMV in this and previous studies $(4,21)$, has the Wsm-1 gene.
Hence, for control of both WSMV and TriMV, Wsm-1 would be preferred to Wsm-2.

The losses in Millennium in our study are similar to those reported for RonL in the study by Seifers et al. (14). It should be noted, however, that in our study, healthy (control treatment) Millennium yield was 28 and $10 \%$ higher than healthy Mace in 2011 and 2012, respectively, indicating a higher yield potential in Millennium compared with Mace in the absence of virus infection.

With yield losses from double inoculation in Millennium of 96 and $81 \%$ in 2011 and 2012, respectively, our study demonstrates the potential devastating effect on yield if a susceptible wheat cultivar is simultaneously infected by the two viruses. Double infections of wheat by the two viruses appear to be common in nature. In a survey of four central Great Plains states, Byamukama et al. (3) found that $91 \%$ of TriMV-positive wheat leaf samples were also positive for WSMV. One strategy that will help to reduce future losses caused by TriMV and WSMV will be to breed for resistance to both viruses. Introgression of Wsm-1 and similar genes (if identified) into new wheat cultivars will be invaluable to wheat farmers and the wheat industry.
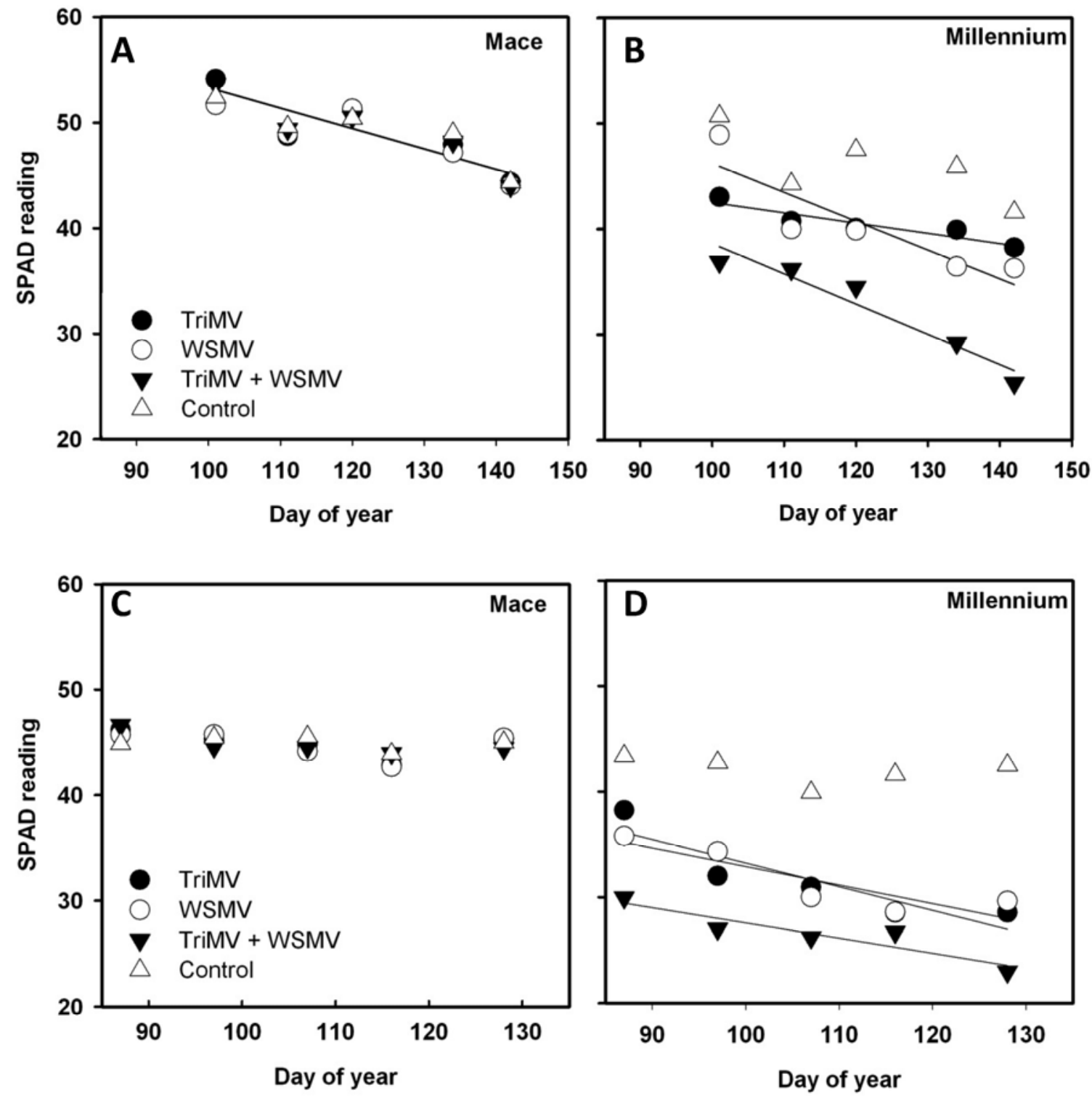

Fig. 2. Relationship between soil plant analysis development (SPAD) readings and day of year (DOY) of sampling among treatments in two winter wheat cultivars, Mace and Millennium, in the 2011 (A and B) and 2012 (C and D) growing seasons. Each data point is the mean of four replicates. Regression equations: Mace, 2011; TriMV: Nonsignificant (NS); WSMV: NS, Mace, TriMV+WSMV, $y=72-0.19 x ; R^{2}=0.84, P=0.0300$; Control, NS. Millennium 2011: TriMV, $y=52-0.10 x ; R^{2}=0.86, P=0.0224$, WSMV, $y=74-0.27 x ; R^{2}=0.79, P=0.0452$, TriMV+WSMV, $y=67-0.29 x ; R^{2}=0.93, P=0.0078$, Control, NS. Mace 2012: TriMV, NS; WSMV, NS; TriMV+WSMV, NS; and Control, NS. Millennium 2012: TriMV, $y=55.5-0.22 x ; R^{2}=0.81, P=0.0385$, WSMV, $y=50.4-0.18 x ; R^{2}=0.78, P=0.0032$, TriMV+WSMV, $y=41.9-0.14 x ; R^{2}=0.84, P=0.0266$, Control, NS. 
In this study, SPAD readings declined over time and were lowest (most severe symptoms) in the TriMV+WSMV treatment in the susceptible cultivar Millennium. This was expected since the double infection causes disease synergism (21). Regression of SPAD readings on DOY revealed a significant, negative linear relationship between the two variables in all virus inoculation treatments in Millennium in both years and in the TriMV+WSMV treatment in Mace in 2011. The decline in SPAD readings over time was most likely due to virus replication and titer buildup over time. It should be noted, however, that SPAD readings are an indicator of symptom severity (intensity of yellowing) and not necessarily titer. A sample that is completely yellow may give a low titer reading (no further virus replication, dead plant cells), whereas a sample that is slightly yellow may give a high titer reading due to active virus replication. Final SPAD readings and AUSPC were, as expected, significantly lower than the control for all virus inoculation treatments in the susceptible Millennium but not in the resistant Mace. Regression of yield on SPAD readings showed a significant, positive linear relationship between the two variables (higher SPAD readings indicate healthier or greener leaf tissue) in Millennium but not in Mace. This was expected because, in Millennium, the effect of virus infection on yield determinants was greater, resulting in a wider range of SPAD readings and corresponding yields.

The data in this study indicate that the yield components/ determinants that were reduced the most by double inoculation of Millennium with TriMV and WSMV were spikes $/ \mathrm{m}^{2}$ and aerial dry matter followed by kernels per spike. These results are consistent with typical symptoms of WSMV in wheat. Staples and Allington (19) reported that severely infected plants may not produce spikes and less seriously affected plants may produce spikes that are poorly filled and often contain shriveled kernels. Hunger et al. (9) showed that inoculation of susceptible winter wheat cultivars with WSMV under field conditions resulted in greater reductions of fertile tillers, yield, and 1,000-kernel weight compared to inoculation of a moderately resistant cultivar with the virus.

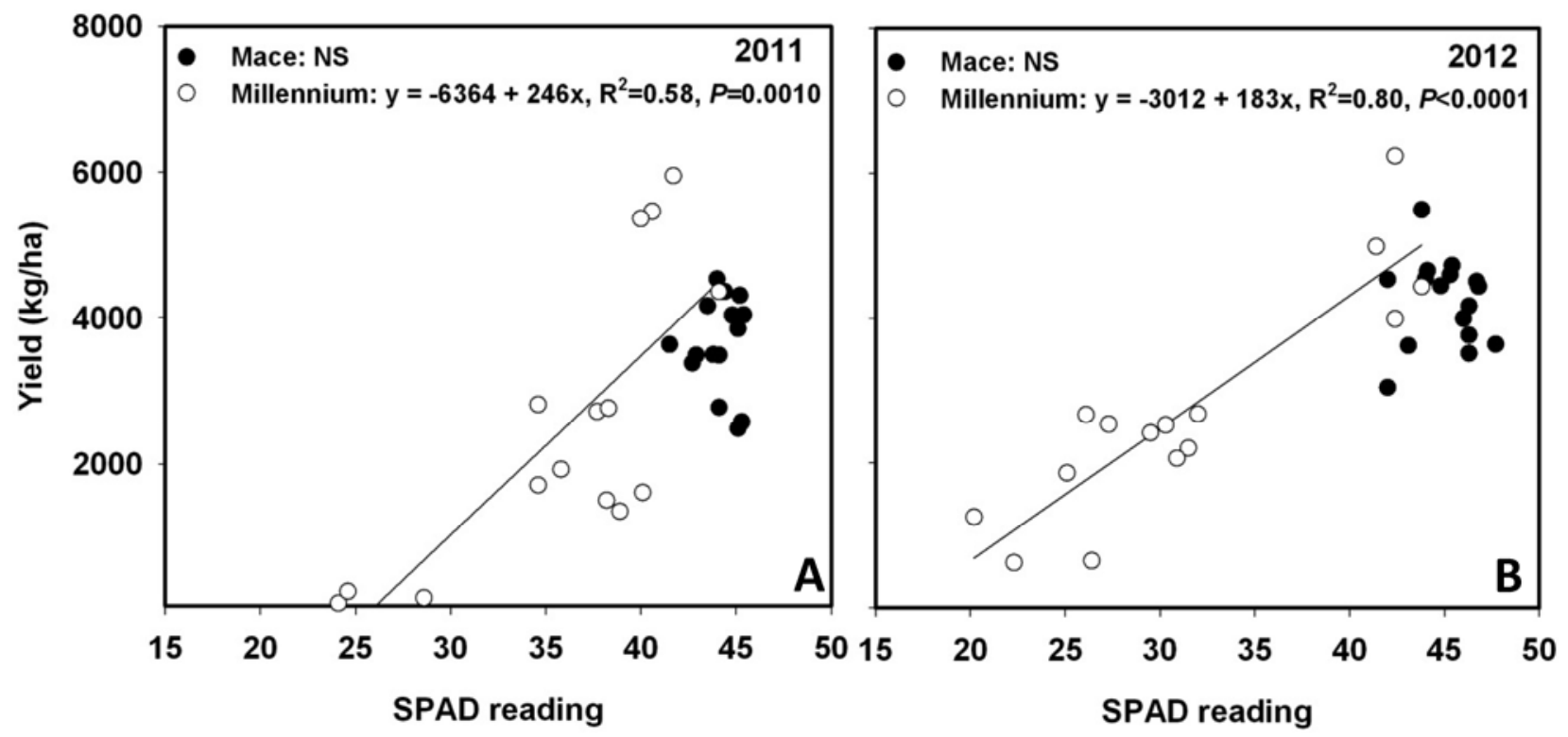

Fig. 3. Relationship between grain yield and soil plant analysis development (SPAD) readings in two winter wheat cultivars, Mace and Millennium, in the 2011 (A) and 2012 (B) growing seasons. Each data point represents a single value from each of the four treatments and four replicates within a cultivar.
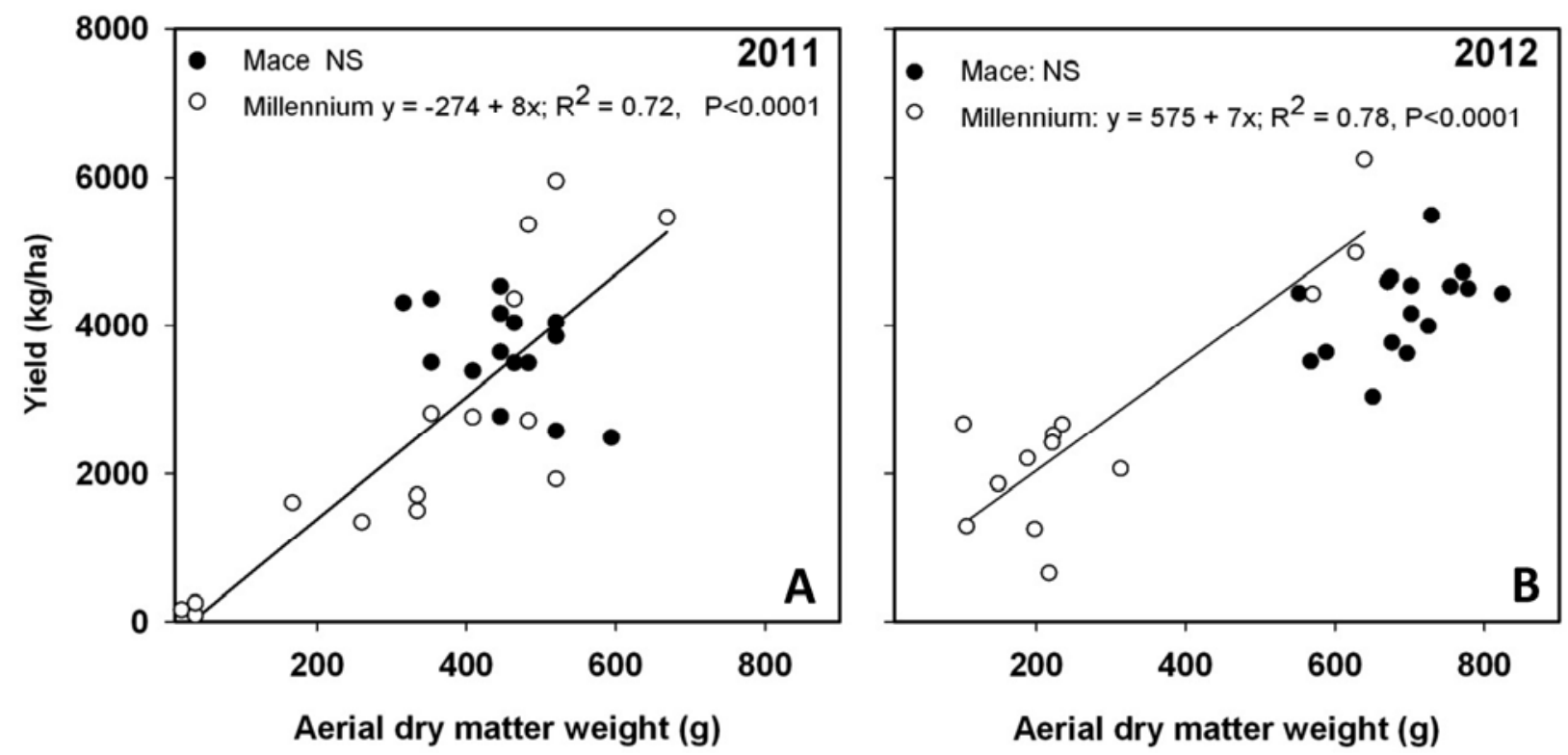

Fig. 4. Relationship between grain yield and aerial dry matter weight in two winter wheat cultivars, Mace and Millennium, in the 2011 (A) and 2012 (B) growing seasons. Each data point represents a single value from each of the four treatments and four replicates within a cultivar. 
In this study, there was a significant, positive relationship between yield and aerial dry matter in Millennium but not in Mace. As stated above for the relationship between yield and SPAD readings, this observation was expected because in the susceptible Millennium, the effect of virus infection on dry matter accumulation was greater than in the resistant Mace, resulting in a wider range of dry matter measurements and corresponding yields.

This study demonstrated the effects of single and double inoculation of a WSMV-susceptible cultivar (Millennium) and a WSMV-resistant cultivar (Mace) with TriMV and WSMV under field conditions. Results indicated that there was a synergistic effect on yield loss when the susceptible cultivar was co-inoculated by both viruses. There was little or no effect on yield from single or double inoculation of Mace with the two viruses, indicating that Mace is also resistant to TriMV under field conditions. More research is needed to elucidate the role of TriMV in yield loss in current and newly released wheat cultivars.

\section{Acknowledgments}

We thank Michael Zwingman, Julie Stevens, and Janelle Millhouse for their invaluable assistance with field work. Funding for this work was provided by the Agriculture and Food Research Initiative Competitive Grants Program Grant Number 2010-85605-20546 from the National Institute of Food and Agriculture.

\section{Literature Cited}

1. Baenziger, P. S., Moreno-Sevilla, B., Peterson, C. J., Shelton, D. R., Elmore, R. W., Nordquiest, P. T., Klein, R. N., Baltensperger, D. D., Nelson, L. A., McVey, D. V., Watkins, J. E., Hein, G., and Hatchett, H. J. 2001. Registration of 'Millennium' wheat. Crop Sci. 41:1367-1369.

2. Burrows, M., Franc, G., Rush, C., Blunt, T., Ito, D., Kinzer, K., Olson, J., O'Mara, J., Price, J., and Tande, C. 2009. Occurrence of viruses in wheat in the Great Plains region, 2008. Online. Plant Health Progress doi:10.1094/PHP-2009-0706-01-RS

3. Byamukama, E., Seifers, D. L., Hein, G. L., De Wolf, E., Tisserat, N. A., Langham, M. A. C., Osborne, L. E., Timmerman, A., and Wegulo, S. N. 2013. Occurrence and distribution of Triticum mosaic virus in the Central Great Plains. Plant Dis. 97:21-29.

4. Byamukama, E., Tatineni, S., Hein, G. L., Graybosch, R., Baenziger, P. S., French, R., and Wegulo, S. N. 2012. Effects of single and double infections of winter wheat by Triticum mosaic virus and Wheat streak mosaic virus on yield determinants. Plant Dis. 96:859-864.

5. Choi, I. R., French, R., Hein, G. L., and Stenger, D. C. 1999. Fully biologically active in vitro transcripts of the eryophyid mite-transmitted wheat streak mosaic tritimovirus. Phytopathology 89:1182-1185.

6. Edwards, M. C., and McMullen, M. P. 1988. Variation in tolerance to wheat streak mosaic virus among cultivars of hard red spring wheat. Plant Dis. 72:705-707.
7. Graybosch, R., Peterson, C., Baenziger, P., Baltensperger, D., Nelson, L., Jin, Y., Kolmer, J., Seabourn, B., French, R., and Hein, G. 2009. Registration of 'Mace' hard red winter wheat. J. Plant Reg. 3:51-56.

8. Guinta, F., Motzo, R., and Deidda, M. 2002. SPAD readings and associated leaf traits in durum wheat barley and tricale cultivars. Euphytica 125:197-205.

9. Hunger, R. M., Sherwood, J. L., Evans, C. K., and Montana, J. R. 1992 Effects of planting date and inoculation date on severity of wheat streak mosaic in hard red winter wheat cultivars. Plant Dis. 76:1056-1060.

10. Madden, L., Hughes, G., and van den Bosch, F. 2007. The study of Plant Disease Epidemics. American Phytopathological Society, St. Paul, MN.

11. Martin, T. J., and Hackerott, H. L. 1982. Greenhouse seedling technique to determine the reaction of sorghum to maize dwarf mosaic virus strain A Crop Sci. 22:1255-1256.

12. Price, J., Workneh, F., Evett, S., Jones, D., Arthur, J., and Rush, C. 2010. Effects of Wheat streak mosaic virus on root development and water-use efficiency of hard red winter wheat. Plant Dis. 94:766-770.

13. Richardson, A. D., Duigan, S. P., and Berlyn, G. P. 2002. An evaluation of noninvasive methods to estimate foliar chlorophyll content. New Phytol. 153:185-194.

14. Seifers, D. L., Martin, T. J., and Fellers, J. P. 2011. Occurrence and yield effects of wheat infected with Triticum mosaic virus in Kansas. Plant Dis. 95:183-188.

15. Seifers, D. L., Martin, T., Harvey, T. L., Fellers, J. P., and Michaud, J. 2009. Identification of the wheat curl mite as the vector of Triticum mosaic virus. Plant Dis. 93:25-29.

16. Seifers, D. L., Martin, T. J., Harvey, T. L., Fellers, J. P., Stack, J. P., RybaWhite, M., Haber, S., Krokhin, O., Spicer, V., Lovat, N., Yamchuk, A., and Standing, K. G. 2008. Triticum mosaic virus: A new virus isolated from wheat in Kansas. Plant Dis. 92:808-817.

17. Shahwan, I. M., and Hill, J. P. 1984. Identification and occurrence of wheat streak mosaic virus in winter wheat in Colorado and its effects on several wheat cultivars. Plant Dis. 68:579-581.

18. Slykhuis, J. T. 1955. Aceria tulipe Keifer (Acarina: Eriophyidae) in relation to the spread of wheat streak mosaic. Phytopathology 45:116-128.

19. Staples, R., and Allington, W. B. 1956. Streak mosaic of wheat in Nebraska and its control. Univ. Neb. Agric. Exp. Stn. Res. Bull. 178.

20. Stillwell, A. R., Hein, G. L., Zygielbaum, A. I., and Rundquist, D. C. 2013. Proximal sensing to detect symptoms associated with wheat curl mitevectored viruses. Int. J. Remote Sens. 34:4951-4966.

21. Tatineni, S., Graybosch, R. A., Hein, G. L., Wegulo, S. N., and French, R. 2010. Wheat cultivar-specific disease synergism and alteration of virus accumulation during co-infection with Wheat streak mosaic virus and Triticum mosaic virus. Phytopathology 100:230-238.

22. Tatineni, S., Ziems, A. D., Wegulo, S. N., and French, R. 2009. Triticum mosaic virus: A distinct member of the family Potyviridae with an unusually long leader sequence. Phytopathology 99:943-950.

23. Velandia, M., Rejesus, R. M., Jones, D. C., Price, J. A., Workneh, F., and Rush, C. M. 2010. Economic impact of Wheat streak mosaic virus in the Texas High Plains. Crop Prot. 29:699-703.

24. Zadoks, J. C., Chang, T. T., and Konzak, C. F. 1974. A decimal code for the growth stages of cereals. Weed Res. 14:415-421. 